\title{
TNFSF15 promoter polymorphisms increase the susceptibility to small cell lung cancer: a case-control study
}

\author{
Hui Gao ${ }^{1,2+}$, Zeren $\mathrm{Niu}^{1,2+}$, Zhi Zhang ${ }^{3}$, Hongjiao Wu', Yuning Xie ${ }^{1,2}$, Zhenbang Yang ${ }^{4}$, Ang Li ${ }^{1,2}$, \\ Zhenxian Jia ${ }^{1,2}$ and Xuemei Zhang ${ }^{1 *}$ (D)
}

\begin{abstract}
Background: Tumor necrosis factor superfamily member 15 (TNFSF15) is closely related to tumorigenesis and development. This study aimed to investigate the correlations between TNFSF15 polymorphisms and genetic susceptibility to lung cancer.

Methods: This case-control study included 209 small cell lung cancer patients (SCLC), 340 non- small cell lung cancer patients (NSCLC) and 460 health controls. TNFSF15-638 A > G and - 358 T > C polymorphisms were genotyped by polymerase chain reaction-restrictive fragment length polymorphism (PCR-RFLP) analysis. Odds ratio $(\mathrm{OR})$ and $95 \%$ confidence interval $(95 \% \mathrm{Cl})$ were estimated by unconditional logistic regression.

Results: Our results showed that subjects carrying the TNFSF15-638GG genotype or -358CC genotype were more likely to develop SCLC $(-638 \mathrm{GG}, O R=1.84,95 \% \mathrm{Cl}=1.13-2.99 ;-358 \mathrm{CC}, O R=2.44,95 \% \mathrm{Cl}=1.46-4.06)$, but not NSCLC $(P>0.05)$. In stratified analysis, $-638 \mathrm{GG}$ genotype was related to SCLC among males $(O R=1.95,95 \% \mathrm{Cl}=1.09-3.45$, $P=0.023)$ and older patients $(O R=2.93,95 \% C l=1.44-8.68, P=0.006)$. However, $-358 C C$ genotype was associated with SCLC among females $(O R=8.42,95 \% \mathrm{Cl}=2.22-31.89, P=0.002)$ and older subjects with $O R(95 \% C l)$ of 11.04 (3.57-34.15) $(P<0.001)$. Moreover, TNFSF15 -358CC was linked with a higher risk of SCLC among non-smokers $(O R=2.54,95 \% \mathrm{Cl}=1.20-5.35, P=0.015)$ but not among smokers $(O R=1.88,95 \% \mathrm{Cl}=0.92-3.84, P=0.086)$.
\end{abstract}

Conclusion: These findings highlight the importance of TNFSF15 polymorphisms in the development of SCLC.

Keywords: TNFSF15, Lung cancer, Single nucleotide polymorphism, Cancer susceptibility

\section{Background}

Lung cancer is one of the most common malignant tumors worldwide and the first leading cause of cancer-related mortality in China [1, 2]. According to World Health Organization, lung cancer is divided into two main types: non-small cell lung cancer (NSCLC) and small cell lung cancer (SCLC), of which NSCLC accounts for almost $85 \%$ of lung cancer cases [3]. Epidemiological studies have identified several risk factors for lung cancer, such as tobacco smoking, atmospheric pollution and occupational environment challenge [4].

\footnotetext{
* Correspondence: jyxuemei@gmail.com

${ }^{+}$Hui Gao and Zeren Niu contributed equally to this work.

'College of Life Science, North China University of Science and Technology,

Tangshan 063210, China

Full list of author information is available at the end of the article
}

However, many individuals who have been exposed to these risk factors do not get lung cancer during lifetime, so genetic factor is likely play an important role.

The initiation and progression of cancer are closely linked to inflammation and angiogenesis $[5,6]$. As one of potent mediators of inflammation, the tumor necrosis factor (TNF) family plays an important role in the process of immunoregulation and further contributes to cancer development [7]. Tumor necrosis factor superfamily 15 (TNFSF15), also known as vascular endothelial growth inhibitor (VEGI), belongs to the TNF ligand family, which negatively regulates angiogenesis [8]. By stimulating T cell, TNFSF15 is involved in the modulation of inflammation $[9,10]$. Studies have shown that over-expression of TNFSF15 inhibits tumor growth in various cancers

(c) The Author(s). 2019 Open Access This article is distributed under the terms of the Creative Commons Attribution 4.0 International License (http://creativecommons.org/licenses/by/4.0/), which permits unrestricted use, distribution, and reproduction in any medium, provided you give appropriate credit to the original author(s) and the source, provide a link to the Creative Commons license, and indicate if changes were made. The Creative Commons Public Domain Dedication waiver (http://creativecommons.org/publicdomain/zero/1.0/) applies to the data made available in this article, unless otherwise stated. 
whereas reduced expression of TNFSF15 is associated with poor prognosis in cancer patients [11-15].

Single nucleotide polymorphisms (SNPs) in regulatory region of a gene can influence the gene expression and further contribute to the development of various cancers [16-19]. In our previous study, we identified two SNPs $(-638 \mathrm{~A}>\mathrm{G}$ and $-358 \mathrm{~T}>\mathrm{C})$ in the TNFSF15 promoter by direct sequencing, and found that $-358 \mathrm{~T}>\mathrm{C}$ variant changed the transcriptional activity of TNFSF 15 and was significantly associated with the susceptibility to gastric adenocarcinoma [20]. In the present study, we tested if these two variants in the TNFSF15 promoter region contributed to the risk of developing lung cancer by performing a case-control study in a Chinese population.

\section{Methods}

\section{Study population}

This case-control study consisted of 209 SCLC patients, 340 NSCLC patients and 460 healthy controls (Table 1). The 549 cases were collected from Tangshan Gongren Hospital and Tangshan Renmin Hospital affiliated to North China University of Science and Technology in China from 2012 to 2016. None of the patients were treated with any radiotherapy or chemotherapy before blood sampling. All subjects were unrelated ethnic Han Chinese. Control individuals without a history of any cancer were recruited from the same region and frequency-matched to cases according to gender and age. This study was approved by Institutional Review Board of North China University of Science and Technology, and written informed consents were obtained from all participants of their own free will.

\section{TNFSF15 genotyping}

Genomic DNA was extracted from peripheral blood from all participants using TIANamp Blood DNA Kit (TIANGEN, Beijing, China), according to the manufacturer's instructions. PCR-restriction fragment length polymorphism (PCR-RFLP) analysis were applied for TNFSF15 genotyping. The PCR primer pairs for $-638 \mathrm{~A}>\mathrm{G}$ (rs7848647) were $5^{\prime}$ AGT CAC CTC GAT CTG TGG CCTC-3' and $5^{\prime}$-AAT CAC GGC TTG GAG TTG TAA CCTC-3'. The target DNA fragment containing $-358 \mathrm{~T}>\mathrm{C}$ (rs6478109) was amplified with primer pairs, -358 -PF (5'-AAA TGT GAT TTC CGT TTC CCCA-3') and - 358 -PR (5'- AAT ATA CCT GTT CCC TGC ACTG -3'). Briefly, PCR was performed using $6 \mu \mathrm{L}$ reaction mixture containing $10 \mathrm{ng}$ DNA, $0.1 \mu \mathrm{M}$ each primer, and $1 \times$ Taq PCR StarMix with loading dye (Genstar, Beijing, China).The PCR thermal cycling condition consists of an initial denaturation step at $94{ }^{\circ} \mathrm{C}$ for 3 min, followed by 30 cycles of $94^{\circ} \mathrm{C}$ for $40 \mathrm{~s}, 58^{\circ} \mathrm{C}$ for $30 \mathrm{~s}$ and $72{ }^{\circ} \mathrm{C}$ for $15 \mathrm{~s}$, and then a final extension step at $72{ }^{\circ} \mathrm{C}$ for $3 \mathrm{~min}$. PCR products for TNFSF15-638A $>$ G (114 bp) and $-358 \mathrm{~T}>\mathrm{C}(123 \mathrm{bp}$ ) were digested by Rsa $I$ and Bcc $I$ (New England BioLabs, Inc., Beverly, USA) and separated on 3\% agarose gel. The genotypes revealed by PCR-RFLP were further confirmed by DNA sequencing (Fig. 1). To ensure the quality control, approximately $10 \%$ of the samples were randomly selected for re-genotyping and all results were in $100 \%$ concordance.

\section{Statistical analysis}

Quanto program was used to calculate the power of the sample size for this case-control study. The power

Table 1 Frequency distribution of select characteristics

\begin{tabular}{|c|c|c|c|c|c|c|c|c|c|c|}
\hline \multirow[t]{3}{*}{ Variables } & \multicolumn{5}{|l|}{$\mathrm{NSCLC}$} & \multicolumn{5}{|l|}{$\mathrm{SCLC}$} \\
\hline & \multicolumn{2}{|c|}{ Case $(n=340)$} & \multicolumn{2}{|c|}{ Controls $(n=460)$} & \multirow[t]{2}{*}{$P$ value ${ }^{*}$} & \multicolumn{2}{|c|}{ Case $(n=209)$} & \multicolumn{2}{|c|}{ Controls $(n=460)$} & \multirow[t]{2}{*}{$P$ value } \\
\hline & No & (\%) & No & (\%) & & No & (\%) & No & (\%) & \\
\hline Gender & & & & & 0.301 & & & & & 0.862 \\
\hline Male & 237 & 69.7 & 336 & 73.0 & & 154 & 73.7 & 336 & 73.0 & \\
\hline Female & 103 & 30.3 & 124 & 27.0 & & 55 & 26.3 & 124 & 27.0 & \\
\hline Age & & & & & 0.139 & & & & & 0.151 \\
\hline$<60$ & 187 & 55.0 & 277 & 60.2 & & 138 & 66.0 & 277 & 60.2 & \\
\hline$\geq 60$ & 153 & 45.0 & 183 & 39.8 & & 71 & 34.0 & 183 & 39.8 & \\
\hline Range & $27-84$ & & $18-84$ & & & 30-92 & & $18-84$ & & \\
\hline Median & 58 & & 56.2 & & & 55 & & 56.2 & & \\
\hline Smoking status & & & & & 0.252 & & & & & 0.431 \\
\hline Non-smoker & 187 & 55.0 & 233 & 50.7 & & 99 & 47.8 & 233 & 50.7 & \\
\hline Smoker & 153 & 45.0 & 227 & 49.3 & & 110 & 52.2 & 227 & 49.3 & \\
\hline Pack year of smoking & & & & & $<0.001$ & & & & & $<0.001$ \\
\hline$<30$ & 59 & 38.6 & 153 & 67.4 & & 37 & 33.7 & 153 & 67.4 & \\
\hline$\geq 30$ & 94 & 61.4 & 74 & 32.6 & & 73 & 66.4 & 74 & 32.6 & \\
\hline
\end{tabular}

"Two-sided $x 2$ test 


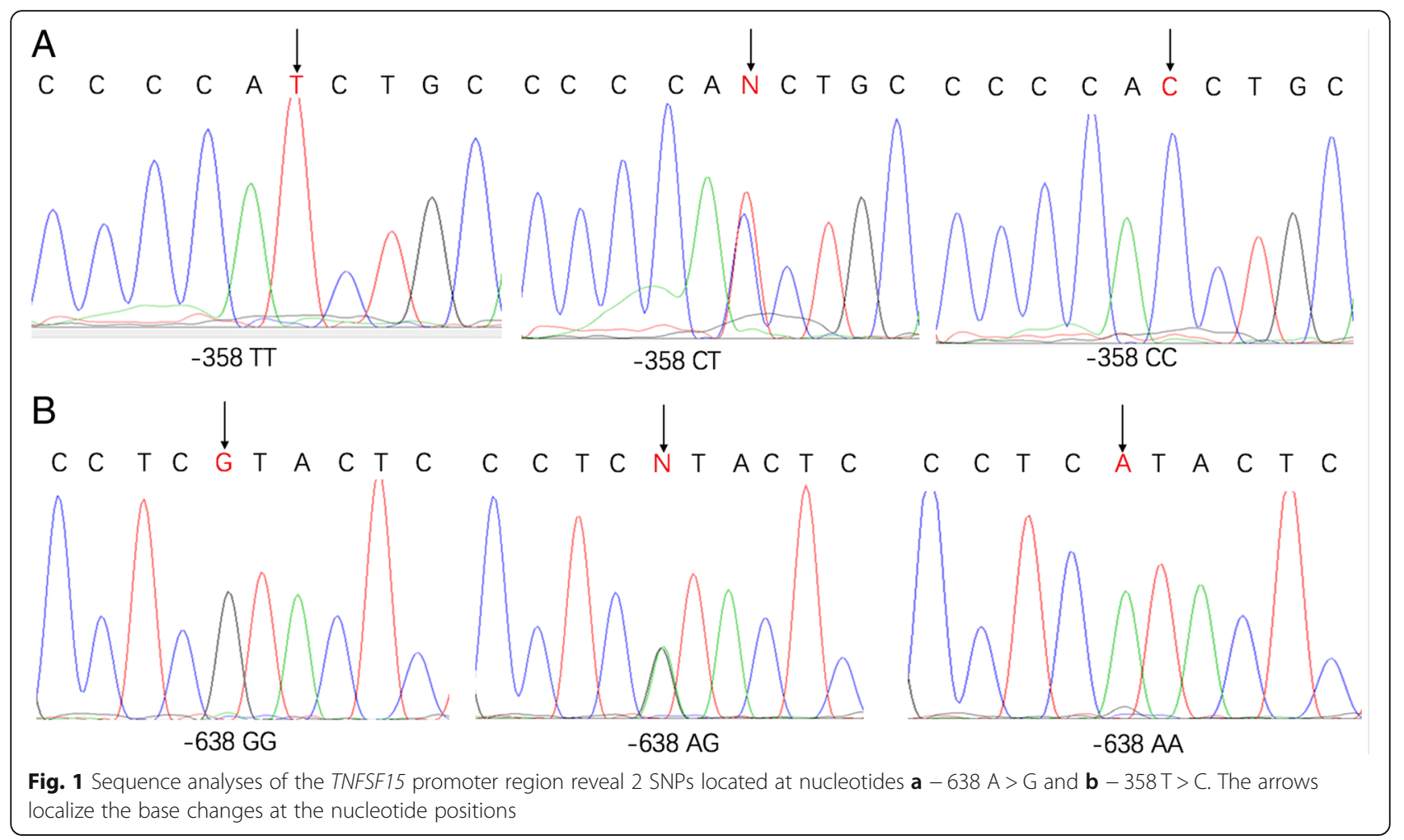

estimation was performed, which indicated that our sample size is sufficient for the case-control study. Differences of basic characteristics in cases and control subjects were compared using the $\chi^{2}$ test. Pearson goodness-of-fit $x^{2}$ test was performed to test whether the distribution of genotypes in the control group was in accordance with Hardy-Weinberg Equilibrium (HWE). Odd ratios (ORs) and 95\% Confidence interval (CI) were calculated by unconditional logistic regression model to evaluate the association of TNFSF15 genetic variations with the susceptibility to lung cancer. The smoking status of pack-years was determined as an indicator of the cumulative cigarette dose level (pack-years cigarettes per day $/ 20 \times$ years smoked). Light and heavy smokers were categorized by using 30 as the cut-off point [21]. Older and younger subjects were sub-grouped by using 60 as the cut-off point (https://www.who.int). All statistical calculations were performed using SPSS version 23.0 (SPSS Inc., Chicago, IL).

\section{Results}

Demographic and clinical characteristics of lung cancer cases and controls

Demographic and clinical characteristics of lung cancer cases and controls are shown in Table 1. There was no significant difference in gender, age and smoking status between NSCLC or SCLC cases and healthy controls $(P>$ $0.05)$. In terms of the amount of smoking, the significant difference was showed between lung cancer group and control group $(P<0.001$ for NSCLC and $P<0.001$ for SCLC). The proportion of heavy smokers in SCLC and NSCLC patients (66.4 and 61.4\%) was significantly higher than that in healthy controls (32.6\%).

\section{Association of TNFSF15 variants with the risk of lung cancer}

Tables 2 and 3 present the genotypes of TNFSF15$638 \mathrm{~A}>\mathrm{G}$ and $-358 \mathrm{~T}>\mathrm{C}$ variants in lung cancer patients and controls. Genotype distributions of TNFSF15-638A > $\mathrm{G}$ and $-358 \mathrm{~T}>\mathrm{C}$ in controls were conformed to be in the Hardy-Weinberg equilibrium (HWE) $(P=0.32$ and $P=0.78$, respectively). We used unconditional logistic regression to assess the association of TNFSF15 SNPs with the risk of lung cancer. For the TNFSF15-638A > G polymorphism, we found that GG genotype carriers had a significantly elevated risk for developing SCLC $(O R=1.84,95 \% C I=1.13-$ 2.99), but not for developing NSCLC $(O R=1.11,95 \% C I=$ 0.74-1.67), in comparison to those with AA genotype. For the TNFSF15 -358 T > C variant, our data showed that CC genotype and $\mathrm{CT}$ genotype were associated with a higher risk of SCLC $(O R=2.44,95 \% C I=1.46-4.06 ; \mathrm{OR}=2.00$, $95 \% C I=1.26-3.19)$ as compared to TT genotype. However, we did not find that the TNFSF15 -358 $\mathrm{T}>\mathrm{C}$ polymorphism was associated with the susceptibility to NSCLC with an OR (95\% CI) of 1.45 (0.96-2.11) in CT carriers and an OR (95\% CI) of 1.24 (0.86-1.76) in CC carriers, respectively. 
Table 2 Genotype frequencies of TNFSF15 polymorphisms and their association with SCLC

\begin{tabular}{|c|c|c|c|c|c|c|}
\hline \multirow[t]{2}{*}{ Genotype } & \multicolumn{2}{|c|}{ Patients $(n=209)$} & \multicolumn{2}{|c|}{ Controls $(n=460)$} & \multirow[t]{2}{*}{ OR $(95 \% C l)^{a}$} & \multirow[t]{2}{*}{$P$ value } \\
\hline & No & $(\%)$ & No & $(\%)$ & & \\
\hline \multicolumn{7}{|l|}{$-638 A>G$} \\
\hline AA & 39 & 18.7 & 122 & 26.5 & & \\
\hline$A G$ & 112 & 53.5 & 240 & 52.2 & $1.46(0.95-2.23)$ & 0.084 \\
\hline GG & 58 & 27.8 & 98 & 21.3 & 1.84(1.13-2.99) & 0.014 \\
\hline \multicolumn{7}{|l|}{$-358 \mathrm{~T}>\mathrm{C}$} \\
\hline$\pi$ & 29 & 13.9 & 116 & 25.2 & & \\
\hline $\mathrm{CT}$ & 114 & 54.5 & 233 & 50.7 & $2.00(1.26-3.19)$ & 0.004 \\
\hline CC & 66 & 31.6 & 111 & 24.1 & $2.44(1.46-4.06)$ & 0.001 \\
\hline
\end{tabular}

${ }^{a}$ Adjusted for age, gender, and smoking status

\section{Stratification analysis of the TNFSF15 polymorphism and the risk of SCLC}

To evaluate the effect of smoking status and non-modifiable risk factors (age and gender) on the association of TNFSF15-638A > G with the risk of SCLC, we performed stratification analysis (Table 4). When stratified by gender, the TNFSF15-638GG genotype was associated with an increased risk of SCLC among males compared with the AA genotype $(O R=1.95,95 \% C I=$ 1.09-3.45, $P=0.023)$, but not among females. Our data also showed that the risk of SCLC was associated with the -638GG genotype among older subjects with an $O R$ (95\% CI) of 2.93 (1.44-8.68), but not among younger subjects with an $O R(95 \% C I)$ of $1.28(0.71-2.34)$. However, no effect of the TNFSF15-638A > G variation on the risk of SCLC was found in stratified analysis based on smoking status.

We then performed stratification analysis to evaluate the association of TNFSF15 $-358 \mathrm{~T}>\mathrm{C}$ genotypes with SCLC (Table 5). Compared with the TT genotype, the CC genotype was associated with a higher risk of SCLC among females $(O R=8.42, \quad 95 \% C I=2.22-31.89, \quad P=$

Table 3 Genotype frequencies of TNFSF15 polymorphisms and their association with NSCLC

\begin{tabular}{|c|c|c|c|c|c|c|}
\hline \multirow[t]{2}{*}{ Genotype } & \multicolumn{2}{|c|}{ Patients $(n=340)$} & \multicolumn{2}{|c|}{ Controls $(n=460)$} & \multirow[t]{2}{*}{$O R(95 \% C l)^{a}$} & \multirow[t]{2}{*}{$P$ value } \\
\hline & No & $(\%)$ & No & $(\%)$ & & \\
\hline \multicolumn{7}{|l|}{$-638 A>G$} \\
\hline$A A$ & 90 & 26.5 & 122 & 26.5 & & \\
\hline$A G$ & 171 & 50.3 & 240 & 52.2 & $0.97(0.69-1.36)$ & 0.867 \\
\hline GG & 79 & 23.2 & 98 & 21.3 & $1.11(0.74-1.67)$ & 0.605 \\
\hline \multicolumn{7}{|l|}{$-358 \mathrm{~T}>\mathrm{C}$} \\
\hline$\pi$ & 71 & 20.9 & 116 & 25.2 & & \\
\hline CT & 173 & 50.9 & 233 & 50.7 & $1.24(0.86-1.76)$ & 0.248 \\
\hline $\mathrm{CC}$ & 96 & 28.2 & 111 & 24.1 & $1.45(0.96-2.11)$ & 0.074 \\
\hline
\end{tabular}

${ }^{\mathrm{a}}$ Adjusted for age, gender, and smoking status
Table 4 Association of TNFSF15-638A > G polymorphism with SCLC risk stratified by selected variables

\begin{tabular}{|c|c|c|c|c|c|}
\hline \multirow[t]{2}{*}{ Variables } & \multicolumn{3}{|c|}{ Genotypes (Cases/Controls) } & \multirow{2}{*}{$\begin{array}{l}\text { GG/AA model } \\
\text { OR }(95 \% \text { Cl) }\end{array}$} & \multirow[t]{2}{*}{$P$ value } \\
\hline & GG & $A G$ & $\mathrm{AA}$ & & \\
\hline \multicolumn{6}{|l|}{ Gender } \\
\hline Male & $42 / 72$ & $84 / 170$ & $28 / 94$ & $1.95(1.09-3.45)$ & 0.023 \\
\hline Female & $16 / 26$ & $28 / 70$ & $11 / 28$ & $1.41(0.54-3.70)$ & 0.483 \\
\hline \multicolumn{6}{|l|}{ Age } \\
\hline$<60$ & $37 / 62$ & $71 / 149$ & $30 / 66$ & $1.28(0.71-2.34)$ & 0.407 \\
\hline$\geq 60$ & $21 / 36$ & $41 / 91$ & $9 / 56$ & $2.93(1.44-8.68)$ & 0.006 \\
\hline \multicolumn{6}{|l|}{ Smoking status } \\
\hline Non-smoker & $28 / 49$ & $53 / 124$ & $18 / 60$ & $1.79(0.88-3.65)$ & 0.107 \\
\hline Smoker & $30 / 49$ & $59 / 116$ & $21 / 62$ & $1.70(0.86-3.38)$ & 0.130 \\
\hline
\end{tabular}

0.002), but not among males. Age stratification analysis showed that there was a correlation between the CC genotype and the risk of SCLC $(O R=11.04,95 \% C I=$ $3.57-34.15, P=0.000)$ among elders when compared to TT carriers, but not among youngers. In addition, the $\mathrm{CC}$ genotype increased the risk of lung cancer among non-smokers $(O R=2.54,95 \% C I=1.20-5.35, P=0.015)$ compared with the TT genotype.

\section{Discussion}

Small-cell lung cancer (SCLC) is a deadly tumor with poor prognosis, which originates from high-grade malignant neuroendocrine cells [22]. Although sensitive to chemotherapy and radiotherapy, SCLC typically recurs rapidly after primary treatment and the five-year survival is only $6 \%$ after diagnosis [23]. Platinum-etoposide doublet has been officially approved for clinical use against SCLC [23]; however, few improvement has been made in SCLC treatment in past several years. Since SCLC is known as a stubborn cancer, there is an urgent need for the identification of biomarkers that can act as a potential therapeutic target in SCLC.

Table 5 Association of TNFSF15 -358 T > C polymorphism with SCLC risk stratified by selected variables

\begin{tabular}{|c|c|c|c|c|c|}
\hline \multirow[t]{2}{*}{ Variables } & \multicolumn{3}{|c|}{ Genotypes (Cases/Controls) } & \multirow{2}{*}{$\begin{array}{l}C C / T \text { model } \\
\text { OR }(95 \% \text { Cl) }\end{array}$} & \multirow[t]{2}{*}{$P$ value } \\
\hline & $\mathrm{CC}$ & $\mathrm{CT}$ & $\pi$ & & \\
\hline \multicolumn{6}{|l|}{ Gender } \\
\hline Male & $42 / 85$ & $86 / 164$ & $26 / 87$ & $1.66(0.93-2.95)$ & 0.086 \\
\hline Female & $24 / 26$ & $28 / 69$ & $3 / 29$ & $8.42(2.22-31.89)$ & 0.002 \\
\hline \multicolumn{6}{|l|}{ Age } \\
\hline$<60$ & $35 / 71$ & $78 / 146$ & $25 / 60$ & $1.15(0.62-2.15)$ & 0.653 \\
\hline$\geq 60$ & $31 / 40$ & $36 / 87$ & $4 / 56$ & 11.04(3.57-34.15) & $<0.001$ \\
\hline \multicolumn{6}{|l|}{ Smoking status } \\
\hline Non-smoker & $36 / 55$ & $51 / 123$ & $12 / 55$ & $2.54(1.20-5.35)$ & 0.015 \\
\hline Smoker & $30 / 56$ & $63 / 110$ & $17 / 61$ & $1.88(0.92-3.84)$ & 0.086 \\
\hline
\end{tabular}


TNF superfamily members play an important role in cell proliferation, differentiation and apoptosis and are used for clinical treatment, or in clinical trials [24, 25]. TNFSF15, a member of $T N F$ superfamily, is likely to inhibit the growth of tumors by suppressing neovascularization. TNFSF15 inhibits the proliferation of vascular endothelial cells in the G0 and G1 phases of cell cycle, and ultimately inhibits angiogenesis. TNFSF15 gene encodes three splice variants, namely VEGI-174, VEGI-251 and VEGI-192 depending on the number of amino acids included [26]. VEGI-251, also known as TL1A (TNF-like molecule 1A), is the longest one of the splice variants. The combination of TL1A and DR3 (Death Receptor 3) activates different signal transduction pathways by inducing $N F-k B$ to activate initial T cell [10] and activating Caspases cascade to promote cell apoptosis [27]. These processes play an important role in the occurrence and development of tumors.

Till now, a few studies have been carried out to demonstrate the association of TNFSF 15 polymorphisms with the susceptibility to cancer. In our previous study, we found that TNFSF15-638A $>$ G polymorphism was associated with the development of gastric adenocarcinoma [20]. In another study, authors indicated that TNFSF15 rs6478106 is related to the risk of breast cancer in Chinese Han population [28]. In this study, we explored the association of TNFSF15 variants with the susceptibility to lung cancer and found that $-638 \mathrm{~A}>\mathrm{G}$ and $-358 \mathrm{~T}>\mathrm{C}$ variants elevated the risk of SCLC, but not of NSCLC. These findings suggested that the TNFSF15 polymorphisms were involved in the development of various cancer types; however, the specific mechanism is not fully clear. We speculate that the TNFSF15 genetic variation affects the expression of TNFSF15 protein and then controls the downstream signal transduction molecules. These changes affect inflammatory and immune response, and further contribute to the development of cancers. Matijja and Clara found that an intron polymorphism of TNFSF15 (rs6478108) affected the expression level of TNFSF15 and increased NOD2-induced signaling and cytokines through caspase-8-induced IL-1 [29]. In our previous study, we found that the $-358 \mathrm{~T}>\mathrm{C}$ polymorphism eliminates a nuclear factor Y (NF-Y) binding site and the $-358 \mathrm{C}$ containing haplotypes had a significantly decreased reporter gene activity in gastric cells [20].

Tobacco smoking is recognized as one of the most important risk factors contributing to lung cancer [30]. Thus, we analyzed the effects of TNFSF15 variants on SCLC by smoking status. Studies have shown a strong association between tobacco exposure and the development of SCLC [31, 32]. Cigarette smoke contains many carcinogenic chemicals such as nicotine and carbon monoxide tar. The complexity of cigarette smoke makes the mechanisms of developing lung cancer even more complicated. At least, tobacco smoking potentially alters the tumor immune microenvironment by creating DNA damage and causing inflammatory response [33, 34]. TNFSF15 is closely related to the inflammatory response. It has been reported that TNFSF15 can directly induce proinflammatory cytokines [35]. Long-term exposure of DNA to the carcinogens in tobacco smoke will lead to a higher mutation load in SCLC [36]. Our present data showed that TNFSF15 $-358 \mathrm{~T}>\mathrm{C}$ polymorphism was related to SCLC among non-smokers instead of smokers, which needs more studies to explain. After stratified by smoking status, the sample size is not enough to evaluate the risk of this genetic variant with the risk of SCLC.

Age and gender are considered to be risk factors for tumor development and progression [37]. Our study showed the TNFSF15-638GG genotype elevated the risk of SCLC among males and individuals aged 60 years and older. Whether gender is related to the risk of lung cancer is controversial after taking into account smoking [38-40]. Due to the small size of several subgroups, a further larger-scale study needs to be conducted in order to carefully evaluate these findings.

In the future, it is necessary to evaluate the usability of these polymorphisms as a low-cost NSCLC screening tool for predicting individual lung cancer risk.

\section{Conclusion}

Taken together, our results indicated that TNFSF15 promoter polymorphisms might be involved in the development of SCLC.

\section{Abbreviations}

NSCLC: non-small cell lung cancer; SCLC: small cell lung cancer; TNFSF15: Tumor necrosis factor superfamily member 15

\section{Acknowledgments}

The authors thank all patients and control subjects for their participation.

\section{Funding}

This work was supported by Foundation of Hebei high-level talents (A201400155 to X. Zhang) and Key Project of Natural Science Foundation of Hebei province of China (H2017209233 to X. Zhang). The funders were not involved in the design of the study and collection, analysis, and interpretation of data and in writing the manuscript.

\section{Availability of data and materials}

The datasets used during the current study are available from the corresponding author on reasonable request.

\section{Authors' contributions}

HG and ZN: acquisition, analysis, and interpretation of data; drafting the manuscript. ZZ and HW: data collection and analysis. YX, ZY, AL, ZJ: DNA extraction; acquisition and interpretation of data. $X Z$ : design of the work, analysis and interpretation of data, revision of the article, final approval of the version to be published. All authors read and approved the final manuscript.

Ethics approval and consent to participate

All the study procedures were approved by the Ethics Committee of North China University of Science and Technology (2016134) and written informed consents were obtained from all participants of their own free will. 


\section{Consent for publication}

Not applicable.

\section{Competing interests}

The authors declare that they have no competing interests.

\section{Publisher's Note}

Springer Nature remains neutral with regard to jurisdictional claims in published maps and institutional affiliations.

\section{Author details}

${ }^{1}$ College of Life Science, North China University of Science and Technology, Tangshan 063210, China. ${ }^{2}$ School of Public Health, North China University of Science and Technology, Tangshan 063210, China. ${ }^{3}$ Affliated Tangshan Gongren Hospital, North China University of Science and Technology, Tangshan 063000, China. ${ }^{4}$ School of Basic Medical Sciences, North China University of Science and Technology, Tangshan 063210, China.

Received: 16 September 2018 Accepted: 31 January 2019

\section{Published online: 08 February 2019}

\section{References}

1. Ferlay J, Colombet M, Soerjomataram I, Mathers C, Parkin DM, Piñeros M, Znaor A, Bray F: ; 2018.

2. Chen $W$, Zheng $R$, Baade PD, Zhang $S$, Zeng $H$, Bray F, Jemal $A, Y u X Q$, He J. Cancer statistics in China, 2015. CA Cancer J Clin. 2016;66(2):115-32.

3. Herbst RS, Heymach JV, Lippman SM. Lung cancer. N Engl J Med. 2008; 359(13):1367-80.

4. de Groot P, Munden RF. Lung cancer epidemiology, risk factors, and prevention. Radiol Clin N Am. 2012·50(5):863-76.

5. Ono M. Molecular links between tumor angiogenesis and inflammation: inflammatory stimuli of macrophages and cancer cells as targets for therapeutic strategy. Cancer Sci. 2008;99(8):1501-6.

6. Grivennikov SI, Greten FR, Karin M. Immunity, inflammation, and cancer. Cell. 2010;140(6):883-99.

7. Sedger LM, McDermott MF. TNF and TNF-receptors: from mediators of cell death and inflammation to therapeutic giants - past, present and future. Cytokine Growth Factor Rev. 2014;25(4):453-72.

8. Grimaldo S, Tian F, Li LY. Sensitization of endothelial cells to VEGI-induced apoptosis by inhibiting the NF-kappaB pathway. Apoptosis : an international journal on programmed cell death. 2009;14(6):788-95.

9. Takedatsu H, Michelsen KS, Wei B, Landers CJ, Thomas LS, Dhall D, Braun J, Targan SR. TL1A (TNFSF15) regulates the development of chronic colitis by modulating both T-helper 1 and T-helper 17 activation. Gastroenterology. 2008;135(2):552-67.

10. Migone TS, Zhang J, Luo X, Zhuang L, Chen C, Hu B, Hong JS, Perry JW, Chen SF, Zhou JX, et al. TL1A is a TNF-like ligand for DR3 and TR6/DCR3 and functions as a T cell costimulator. Immunity. 2002;16(3):479-92.

11. Hou W, Medynski D, Wu S, Lin X, Li LY. VEGI-192, a new isoform of TNFSF15, specifically eliminates tumor vascular endothelial cells and suppresses tumor growth. Clinical cancer research : an official journal of the American Association for Cancer Research. 2005:11(15):5595-602.

12. Cavallini C, Lovato O, Bertolaso A, Zoratti E, Malpeli G, Mimiola E, Tinelli M, Aprili $F$, Tecchio C, Perbellini O, et al. Expression and function of the TL1A/ DR3 axis in chronic lymphocytic leukemia. Oncotarget. 2015;6(31):32061-74.

13. Zhang N, Wu P, Shayiremu D, Wu L, Shan H, Ye L, Zhao X, Cai J, Jiang WG, Gong K, et al. Suppression of renal cell carcinoma growth in vivo by forced expression of vascular endothelial growth inhibitor. Int J Oncol. 2013:42(5): 1664-73.

14. Liang PH, Tian F, Lu Y, Duan B, Stolz DB, Li LY. Vascular endothelial growth inhibitor (VEGl; TNFSF15) inhibits bone marrow-derived endothelial progenitor cell incorporation into Lewis lung carcinoma tumors. Angiogenesis. 2011;14(1):61-8.

15. Parr C, Gan CH, Watkins G, Jiang WG. Reduced vascular endothelial growth inhibitor (VEGI) expression is associated with poor prognosis in breast cancer patients. Angiogenesis. 2006;9(2):73-81.

16. Meng Q, Wu S, Wang Y, Xu J, Sun H, Lu R, Gao N, Yang H, Li X, Tang B, et al. MPO promoter polymorphism rs2333227 enhances malignant phenotypes of colorectal Cancer by altering the binding affinity of AP2alpha. Cancer Res. 2018;78(10):2760-9.
17. Dimitrakopoulos FD, Antonacopoulou AG, Kottorou AE, Maroussi S, Panagopoulos N, Koukourikou I, Scopa C, Kalofonou M, Koutras A Makatsoris T, et al. NF-kB2 genetic variations are significantly associated with non-small cell lung Cancer risk and overall survival. Sci Rep. 2018;8(1):5259.

18. Chen J, Jiang Y, Zhou J, Liu S, Gu Y, Jin G, Hu Z, Ma H, Shen H, Dai J: Genetic Variants in the Promoter Region of miR-10b and the Risk of Breast Cancer. 2017, 2017:2352874.

19. Capasso M, McDaniel LD, Cimmino F, Cirino A, Formicola D, Russell MR, Raman P, Cole KA, Diskin SJ. The functional variant rs34330 of CDKN1B is associated with risk of neuroblastoma. J Cell Mol Med. 2017;21(12):3224-30.

20. Zhang Z, Yu D, Lu J, Zhai K, Cao L, Rao J, Liu Y, Zhang X, Guo Y. Functional genetic variants of TNFSF15 and their association with gastric adenocarcinoma: a case-control study. PLoS One. 2014;9(9):e108321.

21. Pinsky PF, Zhu CS, Kramer BS: Lung cancer risk by years since quitting in 30 + pack year smokers. J Med Screen 2015, 22(3):0969141315579119.

22. Fruh M, De Ruysscher D, Popat S, Crino L, Peters S, Felip E. Small-cell lung cancer (SCLC): ESMO clinical practice guidelines for diagnosis, treatment and follow-up. Ann Oncol : official journal of the European Society for Medical Oncology. 2013:24(Suppl 6):vi99-105.

23. Pietanza MC, Byers LA, Minna JD, Rudin CM. Small cell lung cancer: will recent progress lead to improved outcomes? Clinical cancer research : an official journal of the American Association for Cancer Research. 2015;21(10): 2244-55.

24. Martinez-Escala ME, Posligua AL, Wickless H, Rutherford A, Sable KA, RubioGonzalez B, Zhou XA, Kaplan JB, Pro B, Choi J, et al. Progression of undiagnosed cutaneous lymphoma after anti-tumor necrosis factor-alpha therapy. J Am Acad Dermatol. 2018;78(6):1068-76.

25. Wakelee HA, Patnaik A, Sikic BI, Mita M, Fox NL, Miceli R, Ullrich SJ, Fisher GA, Tolcher AW. Phase I and Pharmacokinetic study of lexatumumab (HGSETR2) given every 2 weeks in patients with advanced solid tumors. Annals of oncology : official journal of the European Society for Med Oncol. 2010; 21(2):376-81.

26. Yu J, Tian S, Metheny-Barlow L, Chew LJ, Hayes AJ, Pan H, Yu GL, Li LY. Modulation of endothelial cell growth arrest and apoptosis by vascular endothelial growth inhibitor. Circ Res. 2001;89(12):1161-7.

27. Bittner S, Knoll G, Fullsack S, Kurz M, Wajant H, Ehrenschwender M. Soluble TL1A is sufficient for activation of death receptor 3. FEBS J. 2016;283(2):323-36.

28. Han S, Liu L, Xu F, Chen S, Yuan W, Fu Z, Li D, Li D. A case-control study about the association between vascular endothelial growth inhibitor gene polymorphisms and breast cancer risk in female patients in Northeast China. Chinese journal of cancer research $=$ Chung-kuo yen cheng yen chiu. 2016; 28(4):435-43.

29. Hedl M, Abraham C. A TNFSF15 disease-risk polymorphism increases pattern-recognition receptor-induced signaling through caspase-8-induced IL-1. Proc Natl Acad Sci U S A. 2014:111(37):13451-6.

30. Thun MJ, Lally CA, Flannery JT, Calle EE, Flanders WD, Heath CW Jr. Cigarette smoking and changes in the histopathology of lung cancer. J Natl Cancer Inst. 1997:89(21):1580-6.

31. Ou SH, Ziogas A, Zell JA. Prognostic factors for survival in extensive stage small cell lung cancer (ED-SCLC): the importance of smoking history, socioeconomic and marital statuses, and ethnicity. J thoracic oncology: official publication of the International Association for the Study of Lung Cancer. 2009:4(1):37-43.

32. Varghese AM, Zakowski MF, Yu HA, Won HH, Riely GJ, Krug LM, Kris MG, Rekhtman N, Ladanyi M, Wang L, et al. Small-cell lung cancers in patients who never smoked cigarettes. J thoracic oncology : official publication of the International Association for the Study of Lung Cancer. 2014;9(6):892-6.

33. Desrichard A, Kuo F, Chowell D, Lee KW, Riaz N, Wong RJ, Chan TA, Morris LGT. Tobacco smoking-associated alterations in the immune microenvironment of squamous cell carcinomas. J Natl Cancer Inst. 2018.

34. Rom O, Avezov K, Aizenbud D, Reznick AZ. Cigarette smoking and inflammation revisited. Respir Physiol Neurobiol. 2013;187(1):5-10.

35. Jin S, Chin J, Seeber S, Niewoehner J, Weiser B, Beaucamp N, Woods J, Murphy C, Fanning A, Shanahan F, et al. TL1A/TNFSF15 directly induces proinflammatory cytokines, including TNFalpha, from CD3+CD161+ T cells to exacerbate gut inflammation. Mucosal Immunol. 2013;6(5):886-99.

36. Pleasance ED, Stephens PJ, O'Meara S, McBride DJ, Meynert A, Jones D, Lin ML, Beare D, Lau KW, Greenman C, et al. A small-cell lung cancer genome with complex signatures of tobacco exposure. Nature. 2010;463(7278):184-90.

37. Patricia DG, Munden RF. Lung cancer epidemiology, risk factors, and prevention. Radiol Clin N Am. 2012;50(5):863-76. 
38. Brownson RC, Chang JC, Davis JR. Gender and histologic type variations in smokingrelated risk of lung cancer. Epidemiology (Cambridge, Mass). 1992;3(1):61-4.

39. Zang EA, Wynder EL. Differences in lung cancer risk between men and women: examination of the evidence. J Natl Cancer Inst. 1996;88(3-4):183-92.

40. Cook MB, McGlynn KA, Devesa SS, Freedman ND, Anderson WF. Sex disparities in cancer mortality and survival. Cancer epidemiology, biomarkers \& prevention : a publication of the American Association for Cancer Research, cosponsored by the American Society of Preventive Oncology. 2011;20(8):1629-37.

Ready to submit your research? Choose BMC and benefit from:

- fast, convenient online submission

- thorough peer review by experienced researchers in your field

- rapid publication on acceptance

- support for research data, including large and complex data types

- gold Open Access which fosters wider collaboration and increased citations

- maximum visibility for your research: over $100 \mathrm{M}$ website views per year

At $\mathrm{BMC}$, research is always in progress.

Learn more biomedcentral.com/submissions 